\title{
Indicators of Low-Carbon Management in the Leisure Industry: Research Using Examples in Taiwan and China
}

\author{
Hsin-Yu Shih and Ying-Sheng Yao * \\ Department of International Business Studies, National Chi Nan University, Nantou County 54561, Taiwan; \\ hyshih@ncnu.edu.tw \\ * Correspondence: s100212907@ncnu.edu.tw; Tel.: +886-912-858-623; Fax: +886-49-2912595
}

Received: 6 March 2020; Accepted: 20 May 2020; Published: 25 May 2020

\begin{abstract}
This study aimed to establish indicators of low-carbon management in the leisure industries in Taiwan and China to meet the demands of saving energy, reducing carbon emissions and slowing global warming. The Pushin Ranch in Taiwan and Lishan Farm in China were targeted as examples. Quantitative indicators were identified through interviews and questionnaire surveys with experts from the industrial, governmental and academic sectors, as well as data integration and statistical analysis using the Delphi method and a paired-samples $t$ test. On the basis of 11 major sustainable tourism indicators proposed by the United Nations World Tourism Organization and the relevant literature, three dimensions were selected for investigation, namely organizational management and operation, ecotourism and social collaboration, along with five operational indicators and 42 assessment indicators. After the expert questionnaire and $t$ test, a set of selection criteria was constructed based on the approval of more than $80 \%$ of the experts; 36 indicators were retained for Taiwan (Pushin Ranch met 17) and 29 were retained for China (Lishan Farm met 13). This allows industrial, governmental and academic units to establish management models and assessment indicators for the leisure industry to meet the demands of energy conservation and carbon reduction.
\end{abstract}

Keywords: leisure industry; low-carbon tourism; Delphi method; Pushin Ranch; Lishan music farm

\section{Introduction}

\subsection{Research Background and Motivation}

According to the conclusions of the United Nations (UN) Climate Change Conference COP25, major decisions about issues related to the global carbon market would be made later in 2020 given the stagnation of the slowing of global warming. In June 2017, President of the United States Donald Trump announced the country's withdrawal from the Paris Climate Agreement, surprising the global community. According to Liu Ya-Chang [1], China is the world's second largest economy and the country with most carbon emissions. If China will play a leading role in the future reduction of $\mathrm{CO}_{2}$ emissions and encourage all countries to join the cause, then international cooperation can still have an effect, even in the age of Trump.

Global warming is affecting public health, food and water safety, migration, as well as peace and security. If measures are not implemented to control climate change, the progress achieved in previous decades cannot continue. Therefore, investment in sustainable development reduces greenhouse gas emissions and improves adaptation to climate change. As such, climate change countermeasures facilitate sustainable development, constituting a reciprocal relationship.

At present, according to preliminary statistics announced by the UN World Tourism Organization (UNWTO), the number of international visitors (tourists who stay in a destination overnight) worldwide 
in 2018 was 1.4 billion, which was 6\% more than the previous year. According to a report by Huang Yen for TechNews [2] (2018), the scale of global tourism amounts to trillions of US\$. As people's earnings are increasing, competition is growing among low-cost airlines and flight ticket prices are dropping, which greatly affects greenhouse gas emissions; however, effective methods of controlling the pollution caused by the booming global tourism industry remain to be developed.

In 2015, China's $\mathrm{CO}_{2}$ emissions were approximately 10.4 billion metric tons, accounting for $29 \%$ of total global emissions, exceeding those of the United States (15\%) and the European Union (10\%), topping the countries that emitted the most $\mathrm{CO}_{2}$ [3]. Thus, China must play a key role in carbon reduction. Furthermore, if efforts can be invested into research, providing indicators for low-carbon management as improvement goals for the leisure industry can contribute to carbon reduction, because this industry manages destinations that tourists commonly visit. As for Taiwan, the promotion of low-carbon tourism was initiated earlier. The authors of the present study sought to research low-carbon management indicators in the leisure industries in Taiwan and China and provide data regarding the similarities and differences for future use.

\section{Research Objectives}

This study mainly explored assessment indicators of low-carbon tourism for the leisure industries in Taiwan and China, with the expectation that they would be used by attraction site managers to examine their compliance with low-carbon management demands. Pushin Ranch in Taiwan and Nanjing Lishan Music Farm in China were used as examples for verification. The research objectives were as follows:

1. To provide low-carbon management indicators for the self-examination of tourist attractions to solve pollution problems in the tourism industry.

2. To analyze the similarities and differences between Taiwan and China in terms of low-carbon management indicators. The results can provide references for the industrial, governmental and academic sectors for creating management mechanisms as well as planning and implementing policies.

\section{Materials and Methods}

\subsection{Importance of Low-Carbon Tourism}

According to Scott et al., [4] (2008) the Second International Conference on Climate Change and Tourism (Davos, Switzerland, October 2007) was a milestone event that brought together a wide variety of stakeholders and delivered a clear commitment for action to respond to the climate change challenge. It underscored the need for the tourism sector to rapidly respond to climate change if it is to develop in a sustainable manner, which will require actions to mitigate the greenhouse gas emissions from the tourism sector, derived especially from transport and accommodation activities and adapt tourism businesses and destinations to changing climate conditions; however many people remain ignorant of the gravity of global warming caused by the tourism industry. An estimation was made by the scientists at the University of Sydney which combined three large-scale international databases and calculated the emissions of all types of greenhouses gases, avoiding previous calculations by only estimating $\mathrm{CO}_{2}$ emissions. They published their results in the journal Nature Climate Change, which indicated that the carbon footprint of global tourism might account for nearly $8 \%$ of total emissions, more than the double of the previous estimation. In 1987, the United Nations World Commission on Environment and Development promoted the concept of sustainable development. Sustainability was first proposed by ecologists in the form of ecological sustainability, which requires the reduction of $\mathrm{CO}_{2}$ emissions. Ecotourism has become the basic concept of international conservation and sustainable development. In particular, low-carbon tourism contributes the most to energy conservation and carbon reduction. The leisure industry is an integral and primary part of the whole tourism industry and requires management through indicators for control and assessment. 


\subsection{Definition of Low-Carbon Tourism}

Low-carbon tourism is a form of tourism characterized by reduced $\mathrm{CO}_{2}$ emissions; it is an in-depth form of ecotourism [5]. In terms of the leisure industry, low-carbon tourism advocates the preservation of the original landscape to the greatest extent possible; the employment of eco-engineering; the active use of new low-carbon products; the extensive use of energy-saving, water-saving and emission-reduction techniques; avoiding the construction of an excessive amount of recreational facilities; the implementation of energy management; control over the total carrying capacity; the reduction of greenhouse gas emissions; the active development of a sustainable economy; upgrading of the tourism industry; advancing of the tourism industry's upstream and downstream sectors; and increasing of the rate of production from resources through the entire industry chain, thereby eventually achieving enhanced growth with less resource waste and energy demand. Furthermore, tourists should be more widely informed that the low-carbon tourism experience is still a new technique and concept; tourism activities such as carbon neutral tourism are both a delight and a responsibility. The results corresponded to the literature. Simpson et al. [6] reported that low-carbon tourism features low-carbon scenic spots, environmentally friendly transportation, environmentally certified accommodation and local organic dining. Tang et al. [7] asserted that low-carbon tourism centers on the reduction of carbon emissions during transportation, accommodation, sightseeing, shopping and entertainment. Li [8] proposed that tourism operators and tourists choose transportation, food, clothing, accommodation and educational and recreational activities that minimize carbon emissions.

\subsection{Indicators of Low-Carbon Management}

Indicators of low-carbon management in the leisure industry remain in the development stage. In Taiwan, the Low Carbon and Sustainable Information System of the Executive Yuan's Environmental Protection Administration features six dimensions, namely green ecosystems, energy-saving facilities, green transportation, resource recycling, low-carbon lifestyles and sustainable management, as well as 86 action plans. Tsai [9] studied an indicator system of a low-carbon itinerary arrangement for travel agencies. The system involved the following six dimensions: "Travel knowledge marketing and advertisement," "Arrangements for attractions," "Shopping advertisement," "Transport facilities," "Dining arrangements," and "Feedback," amounting to 25 indicators in total. In a research study by Chen [10], assessment indicators were established for low-carbon tourism; specifically, 31 significant indicators and 30 operational indicators were established from the viewpoints of travel agencies and tourists. In establishing quantitative evaluation indicators for green hotels, Lin et al. [11] (2015) identified 15 certification indicators for green hotels in several countries: energy, water resources, waste management, purchase policy, environmental policy, transportation, food, enterprise environment management, staff participation, harmful substance management, social participation and communication, indoor air quality, customer information, harmful substances and innovation. Furthermore, $\mathrm{Lu}$ [12] identified the following five dimensions in a comparative study on the development potential of low-carbon tours in Taiwan: tourism resources, traffic status, tourism impression, hotel facilities and $\mathrm{CO}_{2}$ emission status. Moreover, Tsao [13] established 24 indicators and the following six dimensions of low-carbon tourism: community low-carbon awareness, innovative low-carbon system, low-carbon tourism experience, low-carbon architecture and landscape design, low-carbon transportation planning and resource utilization and management. In a study on a low-carbon tourism development suitability evaluation model by Wang [14], 53 indicators and six dimensions were included: travel agency (planning and execution agency), transportation, hotel and accommodation, catering services, destination (scenic spots) and local community. In the present study, indicators related to the leisure industry proposed by the Environmental Protection Administration were included because the leisure industry must comply with policies implemented by the government. According to the results of a literature review, the following preliminary indicators were included: environment, landscape, ecosystem, food and drinks, hotel, transportation, low-carbon education, community management and promotion among tourists. In the preliminary selection of indicators, 
the principle was to include as many indicators as possible. Thus, this study referred to the aforementioned literature and adopted the indicator system designed by Lin [15] regarding the eco-attractions' assessment structure in terms of its effects on the environment, society and the economy. Among the three elements of ecotourism, namely tourism, local residents (local communities) and resources, a total of six corresponding relations were found to exist. In addition, this study referred to the relevant literature and collected 68 vital assessment indicators, shown in Figure 1, which were used as the assessment indicators in the first round of an expert questionnaire. Furthermore, research in China was added for an analysis of the similarities and differences between the indicators adopted in China and Taiwan; the results can be used by the industry, governments and universities in the future.

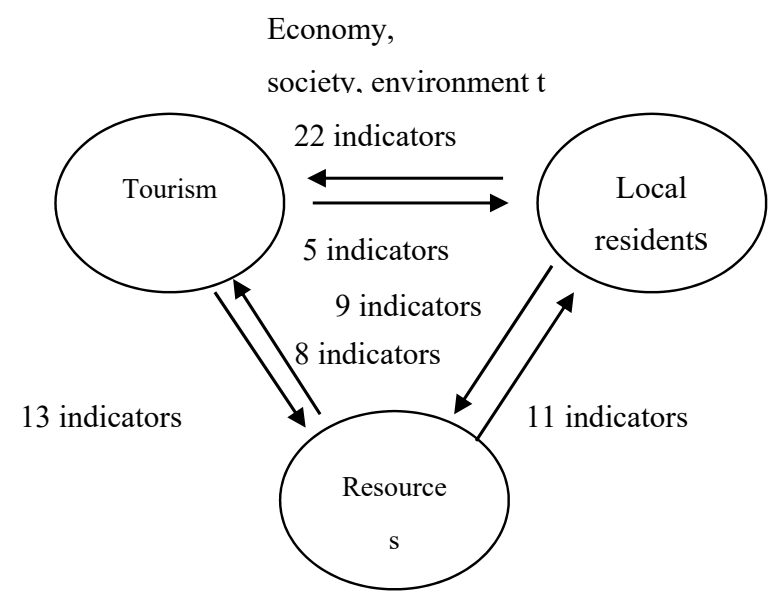

Figure 1. Three elements of ecotourism. Source: Lin [11] (p. 110).

\subsection{Research Procedures}

This study was performed in three stages: dimension selection and questionnaire design, expert questionnaire survey and interviews and statistical analysis of the data. First, assessment criteria for low-carbon management indicators were identified and selected to comply with the research scope of the leisure industry. Then, interview questionnaires with experts in the industrial, governmental and academic sectors were examined, expert interviews were forecasted, data and questionnaire content were integrated and statistical analysis was performed using the Delphi method before the questionnaire item contents were confirmed and revised. Subsequently, expert tests were conducted, namely the second-round pre-test and formal questionnaire. The data were subject to cross-validation using a paired-samples $t$ test analysis. Accordingly, low-carbon management indicators in the leisure industry were established based on the criterion of including indicators with a mean value greater than $80 \%$.

\subsection{Data Analysis}

\subsubsection{Literature Research}

This study collected data from fields related to low-carbon management indicators through a literature review; the sources included master's and $\mathrm{PhD}$ theses, professional journals, government/private publications and research reports.

\subsubsection{Questionnaire Design}

This study was based on the sustainable tourism indicators established by Lin [14], the Low Carbon and Sustainable Homeland action plans announced by Taiwan's Environmental Protection Administration, as well as research by Zo [16] on the major indicators of sustainable tourism proposed by the UNWTO. Moreover, this study established criteria for assessment indicators using the collected literature. After the first round of the expert questionnaires and interviews, the discovered dimensions 
were converged into the following three dimensions: organizational management and operation (encompassing 22 items on facility regulations, three on the control of total carrying capacity and five on stress on environmental education, amounting to 30 items); ecotourism (encompassing eight items on the low-carbon tourism experience); and social collaboration (encompassing four items on community development), for a total of 42 indicators. Subsequently, a second round of the expert questionnaire survey was conducted for further convergence.

\subsection{The Delphi Method}

The Delphi method was invented by Helmer and Dalkey in the 1950s. The Rand Corporation in the United States first used the Delphi method for qualitative forecasting to avoid shortcomings of panel discussions, such as submission to authority or blind obedience to the majority; the method was soon adopted widely. Its main aim is to obtain a consensus among experts rather than compromised opinions. The Delphi method allows experts' knowledge to be explicit to arrive at a set of criteria or standards as a way of acquiring knowledge, which can serve as references for decision making in the future [17].

No strict order exists for Delphi procedures. Usually the research scope and theme are determined first, followed by experts being selected and answering questionnaires in three to four rounds. The first round mainly revolves around the theme and knowledge provision. Opinions are exchanged and a consensus is achieved between the experts throughout the rounds. During the final round, previous conclusions are provided to the experts to yield a final conclusion [18].

According to Murry and Hammons [19], stability is determined using the number of people who choose a certain answer for a question item as a proportion of the total number of people answering the same question item; opinions are deemed stable when this proportion is less than $20 \%$ [18].

\subsubsection{Delphi Expert Selection}

Because the Delphi method targets experts and scholars as survey participants, the selection of these people is one of the key factors affecting the accuracy of the research results. Experts must meet the following criteria [20]:

1. Be representative, authoritative and widely convincing.

2. Have professional diversity and completeness (having too many experts from the same fields is avoided).

Experts, scholars, government officials and private-sector business people from tourism-related fields were invited to participate in this study to arrive at a strategic consensus. According to the aforementioned principles, the expert team members selected for this study were divided into a team from China and one from Taiwan; their qualifications were as follows:

1. Administrative institutions: experts who worked in tourism agencies in Taoyuan, Taiwan and the heads or main planners of tourism development and construction-related departments in Nanjing, China.

2. Academic institutions: experts who conducted in-depth research on tourism in Taoyuan, Taiwan and Nanjing, China or published works related to tourism development.

3. Private-sector business people: experts who worked in the tourism, hospitality or food-service industries as executives, or as senior staff in private-sector tourism-related agencies or corporate bodies in Taoyuan or Nanjing.

When using the Delphi method, the number of experts and scholars for the questionnaire survey is normally no more than 15 for a small panel [21]. In this study, 12 experts, scholars, government officials and private-sector business people from China and 12 from Taiwan (24 people in total) who met the aforementioned principles were chosen to participate in a Delphi method questionnaire survey. Table 1 presents the backgrounds of the experts from Taiwan and China: 
Table 1. Experts' backgrounds.

\begin{tabular}{|c|c|c|c|c|}
\hline Area & Background & Occupation or Department & $\begin{array}{c}\text { Number of } \\
\text { People Chosen }\end{array}$ & Job \\
\hline \multirow[t]{11}{*}{$\begin{array}{l}\text { Taiwanese experts' } \\
\text { backgrounds. }\end{array}$} & $\begin{array}{l}\text { Academic } \\
\text { institution }\end{array}$ & $\begin{array}{l}\text { Leisure and Recreation Management } \\
\text { Department, Kainan University }\end{array}$ & 1 & Certified teacher \\
\hline & & $\begin{array}{l}\text { Department of Tourism and Leisure } \\
\text { Management, China University of Technology }\end{array}$ & 2 & Certified teacher \\
\hline & & $\begin{array}{l}\text { Department of Tourism and Leisure } \\
\text { Management, Vanung University }\end{array}$ & 1 & Certified teacher \\
\hline & $\begin{array}{l}\text { Administration } \\
\text { institution }\end{array}$ & Taoyuan City Yangmei District Office & 2 & $\begin{array}{l}\text { Related business } \\
\text { executives }\end{array}$ \\
\hline & & $\begin{array}{c}\text { Tourism Bureau, Ministry of Transportation } \\
\text { and Communications }\end{array}$ & 1 & $\begin{array}{c}\text { Related business } \\
\text { executives }\end{array}$ \\
\hline & & $\begin{array}{c}\text { Department of Tourism, Taoyuan City } \\
\text { Government }\end{array}$ & 1 & $\begin{array}{l}\text { Related business } \\
\text { executives }\end{array}$ \\
\hline & & Taoyuan Metro & 1 & Management \\
\hline & $\begin{array}{l}\text { Private-sector } \\
\text { business people }\end{array}$ & Great Roots Forestry Spa Resort & 1 & $\begin{array}{l}\text { Business } \\
\text { manager }\end{array}$ \\
\hline & & $\begin{array}{l}\text { Taiwan Recreational Parks } \\
\text { Association Supervisor }\end{array}$ & 1 & $\begin{array}{l}\text { Business } \\
\text { manager }\end{array}$ \\
\hline & & Pushin Ranch & 1 & Management \\
\hline & & subtotal & 12 & \\
\hline \multirow[t]{8}{*}{$\begin{array}{c}\text { Chinese experts' } \\
\text { backgrounds }\end{array}$} & $\begin{array}{l}\text { Academic } \\
\text { institution }\end{array}$ & Nanjing Agricultural University & 4 & Certified teacher \\
\hline & $\begin{array}{l}\text { Administration } \\
\text { institution }\end{array}$ & Nanjing Municipal Tourism Commission & 4 & $\begin{array}{c}\text { Related business } \\
\text { executives }\end{array}$ \\
\hline & $\begin{array}{l}\text { Private-sector } \\
\text { business people }\end{array}$ & Xiao-Kang Ranch & 1 & Management \\
\hline & & Bi-Yuan Ranch & 1 & Management \\
\hline & & Three Kingdoms Village & 1 & Management \\
\hline & & Lishan Music Farm & 1 & Management \\
\hline & & Subtotal & 12 & \\
\hline & & Total & 24 & \\
\hline
\end{tabular}

\subsubsection{Data Processing}

According to Linstone and Turoffz [22], the Delphi method is a research method that converges research results through regular feedback. Each question item was measured on a 5-point scale ranging from not at all important to absolutely essential from 1 to 5 , respectively. If the stability of the assessment criteria of each question item was less than $15 \%$, then this indicates that variations in the opinions of the experts and scholars toward an indicator have stabilized.

After the second round of the questionnaire survey, indicators with a stability greater than $15 \%$ were removed through stability analysis. Then, focusing on the remaining indicators after the second round, the means of the indicators were selected to determine indicators that had reached a level above "important." The indicators that passed the first-round stability analysis and second-round mean selection were then chosen as the low-carbon management indicators of the leisure industry.

\subsection{Case Introductions}

\subsubsection{Overview of Pushin Ranch}

Covering an area of approximately 40 hectares, Pushin Ranch is located at a transit hub where the Sun Yat-sen Freeway, National Freeway 3, and the East-West Expressway intersect. In 1957, in compliance with the government's development of Taiwan's dairy industry, Pushin Ranch became the first private dairy farm with large cows in Taiwan to provide equipment and ground to train dairy farmers; the Ranch also provided interest-free loans on imported Dutch dairy cows to dairy farmers at the time for milk reception, thereby inaugurating Taiwan's dairy business. Later, Pushin Ranch was transformed into a tourist ranch with government assistance in response to the tourism trend and demand for leisure; the focus was shifted to the theme of a cow ecosystem and industry in combination with activities such as vacation leisure and parent-child recreation.

Pushin Ranch is divided into four areas, namely the ecological experience, camping and barbecue, landscaped garden and accommodation and dining areas, thereby satisfying visitors by providing 
leisure, learning and happy experiences at the ranch. The ecological experience area includes a butterfly hall, a rhinoceros beetle rehabilitation zone, dairy industry exhibitions and an aquatic plants area; the camping and barbecue area includes stoves for picnicking and barbecue, a campsite and rain shelters; the landscape garden area includes a European-style garden, a Japanese-style garden, an old banyan tree tunnel, and Chun-Ching Lake; the accommodation and dining area provides Chinese, Western and fast foods and features accommodation in the form of chalets, a Dutch village, and Mediterranean rooms.

\subsubsection{Overview of Lishan Music Farm}

Located in Lishan Village of Dongping Town in Nanjing City's Lishui District, Lishan Music Farm is $45 \mathrm{~km}$ away from Nanjing's urban area. Covering an area of nearly 47 hectares, the ranch possesses hilly landforms typical of Jiangnan, fine idyllic scenery, as well as diverse and agricultural by-products. Visitors can ride horses, try archery, play real-life Counter-Strike, use a self-service barbecue, cook using Taiwanese earth ovens, try shrimp fishing and fish grabbing, and pick fruits and vegetables, and parents can collect eggs with their children. In 2014, Lishan Music Farm was voted by the Jinling Evening News as one of the top 10 summer resorts in Nanjing; in 2015, it was coined the most beautiful village and agricultural attraction in Nanjing, that is, the best agricultural attraction for leisure with an outstanding original ecosystem.

Lishan Music Farm provides visitors with the following facilities and activities: (1) a music plaza over water; (2) horseback riding; (3) real-life Counter-Strike; (4) parent-child egg collecting; (5) manual DIY; (6) picking seasonal fruits and vegetables; (7) a children's playground; (8) equestrian shows; (9) an indoor stadium; (10) a Chinese restaurant; (11) self-service barbecue activities; (12) cooking Beggar's chicken in Taiwanese earth ovens; (13) traditional hand-made snacks; (14) special products from the farm; (15) special accommodation (villas, standard rooms, and scenic concrete pipe houses); and (16) the Hobbit Village. Furthermore, in 2015, Lishan Music Farm exhibited dozens of types of wild vegetables during its Wild Vegetable Festival to promote green living.

\section{Results}

\subsection{Delphi Method Analysis}

Research results of the Delphi method are partially restricted as follows:

1. Experts and scholars were highly homogenous and may have lacked diversity, making the results inadequate. This study used equal numbers of experts in industry, government and academia to mitigate this phenomenon;

2. The knowledge and experience gap between the members of the expert and scholar groups was difficult to quantify. To reduce the gap in this study, industrial, governmental and academic experts in tourism were the subjects of investigation;

3. Although quantitative statistics can represent the majority, a few opinions can be easily ignored. Cautious judgments were used during this study;

4. The Delphi method is a multiple-round question-and-answer method that is unsuitable for time-sensitive research, and this study also involved long-term research.

\subsubsection{Converging and Integrating the Questionnaire Results}

The mean of each question item from the first-round questionnaire was calculated on the basis of the results of the question items in each dimension. The second-round questionnaire was created by removing question items with means lower than four and adding new items suggested by the experts in the first round of questionnaires. 
The analysis results of the first round, displayed as mode and mean values, were attached to the second-round questionnaires. This enabled the experts to refer to all the responses from the first round and reconsider their answers in the second round.

\subsubsection{Stability Analysis of the Delphi Questionnaire}

The stability of the experts' opinions was determined based on the data collected from the two rounds of expert questionnaires. The mean scores of the experts' opinions from the two rounds were examined using statistical tests. No significant differences between the means were found, and therefore the experts' opinions were deemed stable. The two rounds of Delphi questionnaires used in this study were derived from the same source sample. Thus, the differences between the responses in the two rounds were analyzed using a paired-samples $t$ test, which was performed using SPSS 23 (IBM, USA).

Tables 2-4 present the paired-samples $t$ test results; the mean difference signifies the difference between the means of the paired samples. The "significance" in the $t$ test results was denoted by the $P$ value from the paired comparison; if the $P$ value was $<0.05$, then a significant difference would exist between the means of the paired samples, whereas if the P value was $>0.05$, then no significant difference would exist. The results in Tables $2-4$ show that the $P$ values were all greater than 0.05 , indicating that no significant differences existed between the means of the paired samples. This meant that the experts' opinions in the two rounds were stable.

Table 2. Results of the $t$ test for the organizational management and the operation dimension.

\begin{tabular}{|c|c|c|c|c|}
\hline \multirow{3}{*}{$\begin{array}{l}\text { The Organizational Management and } \\
\text { Operation Dimension }\end{array}$} & \multicolumn{4}{|c|}{ Test Results } \\
\hline & \multirow{2}{*}{$\mathrm{T}$} & \multirow{2}{*}{$\begin{array}{l}\text { Significance } \\
\text { (Double-Tailed) }\end{array}$} & \multicolumn{2}{|c|}{ Differences in $95 \%$ Confidence Intervals } \\
\hline & & & Lower Limit & Upper Limit \\
\hline \multicolumn{5}{|l|}{ Facility Regulations } \\
\hline $\begin{array}{c}\text { Preserve the original landscape as much as possible and } \\
\text { avoid constructing too many basic facilities }\end{array}$ & -0.11 & 0.913 & -1.56 & 1.400 \\
\hline $\begin{array}{l}\text { Transform existing facilities and avoid redevelopment as } \\
\text { much as possible }\end{array}$ & 0.123 & 0.903 & -1.39 & 1.570 \\
\hline $\begin{array}{l}\text { Perform construction using eco-engineering as much } \\
\text { as possible }\end{array}$ & -0.277 & 0.784 & -1.73 & 1.320 \\
\hline $\begin{array}{c}\text { Integrate landscape design into the local } \\
\text { natural environment }\end{array}$ & -1.139 & 0.267 & -1.61 & 0.470 \\
\hline Use local plants & -0.045 & 0.964 & -1.74 & 1.670 \\
\hline Avoid introducing too many artificial recreational facilities & 0.380 & 0.707 & -1.33 & 1.920 \\
\hline $\begin{array}{l}\text { Use local materials to integrate recreational facilities } \\
\text { into nature }\end{array}$ & -0.166 & 0.870 & -1.62 & 1.380 \\
\hline $\begin{array}{c}\text { Ensure that recreational facilities' design and construction } \\
\text { comply with safety criteria }\end{array}$ & -0.408 & 0.687 & -1.49 & 1.000 \\
\hline $\begin{array}{l}\text { Use nontoxic agricultural products certified by the } \\
\text { government as much as possible }\end{array}$ & -0.038 & 0.970 & -2.05 & 1.980 \\
\hline Purchase eco-labeled products & -0.478 & 0.637 & -1.53 & 0.950 \\
\hline $\begin{array}{l}\text { Purchase seasonal yields and reduce expenses on } \\
\text { low-temperature preservation }\end{array}$ & -0.471 & 0.642 & -1.32 & 0.830 \\
\hline $\begin{array}{l}\text { Implement proper logistic management and reduce the } \\
\text { scrap rate }\end{array}$ & -0.221 & 0.827 & -1.68 & 1.350 \\
\hline $\begin{array}{l}\text { Ensure the proper disposal of waste } \\
\text { (insuring or outsourcing) }\end{array}$ & -0.204 & 0.840 & -1.53 & 1.250 \\
\hline Use dual-flush and low-flow toilets & 0.378 & 0.709 & -1.14 & 1.650 \\
\hline Use energy-saving electronic appliances & -0.066 & 0.948 & -1.20 & 1.120 \\
\hline $\begin{array}{l}\text { Use natural ventilation and reduce the energy consumption } \\
\text { of air conditioning }\end{array}$ & -0.205 & 0.840 & -1.34 & 1.100 \\
\hline $\begin{array}{c}\text { Adequately use local energy and resources (solar, wind and } \\
\text { water energy) }\end{array}$ & -0.053 & 0.959 & -1.49 & 1.420 \\
\hline Thoroughly collect and classify garbage & -0.045 & 0.964 & -1.74 & 1.670 \\
\hline Increase the ratio of food waste recycled & 0.387 & 0.702 & -1.29 & 1.880 \\
\hline Provide showers instead of bathtubs & 0.202 & 0.841 & -1.58 & 1.920 \\
\hline $\begin{array}{l}\text { Incorporate ecological concepts into the provision of } \\
\text { accommodation and food }\end{array}$ & 0.069 & 0.946 & -1.34 & 1.440 \\
\hline $\begin{array}{l}\text { Incorporate ecological concepts into the management of } \\
\text { accommodation and food }\end{array}$ & 0.006 & 0.995 & -1.55 & 1.560 \\
\hline
\end{tabular}


Table 2. Cont

\begin{tabular}{|c|c|c|c|c|}
\hline \multirow{3}{*}{$\begin{array}{c}\text { The Organizational Management and } \\
\text { Operation Dimension }\end{array}$} & \multicolumn{4}{|c|}{ Test Results } \\
\hline & \multirow{2}{*}{$\mathbf{T}$} & \multirow{2}{*}{$\begin{array}{l}\text { Significance } \\
\text { (Double-Tailed) }\end{array}$} & \multicolumn{2}{|c|}{ Differences in $\mathbf{9 5 \%}$ Confidence Intervals } \\
\hline & & & Lower Limit & Upper Limit \\
\hline \multicolumn{5}{|l|}{ Control over the total carrying capacity } \\
\hline Design of the total carrying capacity & 0.159 & 0.875 & -1.55 & 1.810 \\
\hline Control tourism carrying capacities & 0.345 & 0.733 & -1.27 & 1.780 \\
\hline $\begin{array}{c}\text { Ensure flexible control over carrying capacities according to } \\
\text { environmental conditions }\end{array}$ & -0.315 & 0.755 & -1.23 & 0.900 \\
\hline Stress on environmental education & & & & \\
\hline $\begin{array}{c}\text { Provide information on water and energy conservation to } \\
\text { customers }\end{array}$ & 0.278 & 0.784 & -1.37 & 1.800 \\
\hline Advise customers not to change bed sheets and towels daily & 0.207 & 0.838 & -1.16 & 1.420 \\
\hline Provide appropriate amounts of toiletries and reduce waste & 0.216 & 0.831 & -1.47 & 1.810 \\
\hline $\begin{array}{c}\text { Ask customers to properly separate garbage and recycle } \\
\text { useful resources }\end{array}$ & 0.268 & 0.791 & -1.71 & 2.220 \\
\hline Provide low-carbon environmental lectures & 0.259 & 0.798 & -1.49 & 1.920 \\
\hline
\end{tabular}

Table 3. Results of the $t$ test for the ecotourism dimension.

\begin{tabular}{|c|c|c|c|c|}
\hline \multirow[b]{2}{*}{ Ecotourism Dimension } & \multicolumn{4}{|c|}{ Test Results } \\
\hline & $\mathbf{T}$ & $\begin{array}{c}\text { Significance } \\
\text { (Double-Tailed) }\end{array}$ & $\begin{array}{l}\text { Differences in } 95 \% \\
\text { Lower Limit }\end{array}$ & $\begin{array}{c}\text { Confidence Intervals } \\
\text { Upper Limit }\end{array}$ \\
\hline Low-Carbon Tourism Experience & & & & \\
\hline $\begin{array}{l}\text { Provide tourists with environmental education about } \\
\text { low-carbon tourism }\end{array}$ & 0.875 & 0.875 & -1.55 & 1.810 \\
\hline $\begin{array}{l}\text { Ensure tourists can understand the spirit of } \\
\text { low-carbon tourism }\end{array}$ & 0.768 & 0.768 & -1.51 & 2.020 \\
\hline $\begin{array}{l}\text { Design travel itineraries for tourists to experience the } \\
\text { features of low-carbon tourism }\end{array}$ & 0.917 & 0.917 & -1.64 & 1.810 \\
\hline $\begin{array}{l}\text { Low-carbon ecotourism experiences (time) as a } \\
\text { proportion of an entire trip }\end{array}$ & 0.605 & 0.605 & -1.49 & 2.500 \\
\hline $\begin{array}{l}\text { Tourists' satisfaction with travel itineraries that reflect } \\
\text { the low-carbon tourism experience }\end{array}$ & 0.488 & 0.488 & -1.14 & 2.310 \\
\hline $\begin{array}{l}\text { Whether travel itineraries enable tourists to experience } \\
\text { the importance of environmental sustainability }\end{array}$ & 0.841 & 0.841 & -1.58 & 1.920 \\
\hline $\begin{array}{l}\text { Whether travel itineraries can represent ecological } \\
\text { features and the value of local nature }\end{array}$ & 0.954 & 0.954 & -1.35 & 1.280 \\
\hline Design special activities for tourism experiences & 0.903 & 0.903 & -1.39 & 1.570 \\
\hline
\end{tabular}

Source: Organized by this study.

Table 4. Results of the $t$ test for the social collaboration dimension.

\begin{tabular}{|c|c|c|c|c|}
\hline \multirow{3}{*}{ Social Collaboration Dimension } & \multicolumn{4}{|c|}{ Test Results } \\
\hline & \multirow[b]{2}{*}{$\mathbf{T}$} & \multirow{2}{*}{$\begin{array}{c}\text { Significance } \\
\text { (Double-Tailed) }\end{array}$} & \multicolumn{2}{|c|}{ Differences in $95 \%$ Confidence Intervals } \\
\hline & & & Lower Limit & Upper Limit \\
\hline \multicolumn{5}{|l|}{ Community Development } \\
\hline $\begin{array}{l}\text { Collaboration with local industries regarding } \\
\text { low-carbon issues }\end{array}$ & 0.542 & 0.593 & -1.19 & 2.030 \\
\hline $\begin{array}{c}\text { Community development association's participation in } \\
\text { resolving low-carbon issues }\end{array}$ & 0.475 & 0.639 & -1.41 & 2.250 \\
\hline $\begin{array}{l}\text { Engage in collaboration that exerts positive economic } \\
\text { impacts related to low-carbon issues }\end{array}$ & 0.371 & 0.714 & -1.57 & 2.250 \\
\hline $\begin{array}{l}\text { Exert and extend community industries } \\
\text { and development }\end{array}$ & 0.393 & 0.698 & -1.62 & 2.380 \\
\hline
\end{tabular}

Overall, the results from the two rounds of surveys on the low-carbon indicators of the leisure industry demonstrated a certain extent of stability in the experts' opinions provided in the surveys.

\subsubsection{Validity Analysis of Opinions from the Questionnaires}

This study adopted the following selection criterion used by Hsieh [23] in his study on establishing the indicators of sustainable development for Kaohsiung City, Taiwan: indicators agreed on by more than $80 \%$ of subjects were included. The results were divided into five equal parts. If the mean of an indicator did not reach $80 \%$ (lower than four), the indicator was excluded. Tables $5-7$ show the results of the calculations for the three dimensions. 
Table 5. Indicators of the organizational management and operation dimensions.

\begin{tabular}{|c|c|c|c|c|c|c|}
\hline \multirow{3}{*}{ Dimension } & \multirow{3}{*}{$\begin{array}{l}\text { Operational } \\
\text { Indicator }\end{array}$} & \multirow{3}{*}{ Item } & \multicolumn{2}{|c|}{ Taoyuan Taiwan } & \multicolumn{2}{|c|}{ Nanjing China } \\
\hline & & & \multirow{2}{*}{$\begin{array}{c}\text { Pushin Ranch } \\
\text { Mean } \\
\end{array}$} & \multirow{2}{*}{ Remark } & \multirow{2}{*}{$\begin{array}{c}\text { Lishan Music Farm } \\
\text { Mean }\end{array}$} & \multirow{2}{*}{ Remark } \\
\hline & & & & & & \\
\hline \multirow{30}{*}{$\begin{array}{l}\text { The organizational } \\
\text { management and } \\
\text { operation dimension }\end{array}$} & \multirow{22}{*}{$\begin{array}{l}\text { Facility regulations } \\
\text { reduce, reuse, recycle }\end{array}$} & $\begin{array}{l}\text { Preserve the original landscape as much as possible and avoid constructing too } \\
\text { many basic facilities }\end{array}$ & 4.33 & & 4.33 & \\
\hline & & Transform existing facilities and avoid redevelopment as much as possible & 4.00 & & 4.33 & \\
\hline & & Perform construction using eco-engineering as much as possible & 4.50 & & 4.42 & \\
\hline & & Integrate landscape design into the local natural environment & 4.67 & & 4.83 & \\
\hline & & Use local plants & 4.42 & & 4.17 & \\
\hline & & Avoid introducing too many artificial recreational facilities & 4.25 & & 3.58 & removed \\
\hline & & Use local materials to integrate recreational facilities into nature & 4.25 & & 4.50 & \\
\hline & & $\begin{array}{l}\text { Ensure that recreational facilities' design and construction comply with } \\
\text { safety criteria }\end{array}$ & 4.25 & & 4.75 & \\
\hline & & $\begin{array}{l}\text { Use nontoxic agricultural products certified by the government as much } \\
\text { as possible }\end{array}$ & 3.92 & removed & 4.67 & \\
\hline & & Purchase eco-labeled products & 4.25 & & 4.83 & \\
\hline & & Purchase seasonal yields and reduce expenses on low-temperature preservation & 4.42 & & 4.58 & \\
\hline & & Implement proper logistic management and reduce the scrap rate & 4.33 & & 4.50 & \\
\hline & & Ensure proper disposal of waste (insourcing or outsourcing) & 4.50 & & 4.17 & \\
\hline & & Use dual-flush and low-flow toilets & 4.00 & & 4.00 & \\
\hline & & Use energy-saving electronic appliances & 4.17 & & 4.42 & \\
\hline & & Use natural ventilation and reduce the energy consumption of air conditioning & 4.42 & & 4.33 & \\
\hline & & Adequately use local energy and resources (solar, wind and water energy) & 4.33 & & 4.25 & \\
\hline & & Thoroughly collect and classify garbage & 4.42 & & 4.17 & \\
\hline & & Increase the ratio of food waste recycled & 4.08 & & 3.83 & removed \\
\hline & & Provide showers instead of bathtubs & 3.92 & removed & 4.25 & \\
\hline & & Incorporate ecological concepts into the provision of accommodation and food & 4.08 & & 4.33 & \\
\hline & & Incorporate ecological concepts into the management of accommodation and food & 4.00 & & 4.50 & \\
\hline & \multirow{3}{*}{$\begin{array}{l}\text { Control over the total } \\
\text { carrying capacity }\end{array}$} & Total carrying capacity design & 4.00 & & 4.25 & \\
\hline & & Control tourism carrying capacities & 4.08 & & 3.92 & removed \\
\hline & & $\begin{array}{c}\text { Ensure flexible control over carrying capacities according to } \\
\text { environmental conditions }\end{array}$ & 4.50 & & 4.33 & \\
\hline & \multirow{5}{*}{$\begin{array}{c}\text { Stress on } \\
\text { environmental } \\
\text { education }\end{array}$} & Provide information on water and energy conservation to customers & 4.00 & & 4.08 & \\
\hline & & Advise customers not to change bed sheets and towels daily & 4.17 & & 4.08 & \\
\hline & & Provide appropriate amounts of toiletries and reduce waste & 4.25 & & 3.92 & removed \\
\hline & & Ask customers to properly separate garbage and recycle useful resources & 4.00 & & 4.00 & \\
\hline & & Provide low-carbon environmental lectures & 4.17 & & 3.92 & removed \\
\hline
\end{tabular}


Table 6. Indicators of the ecotourism dimension.

\begin{tabular}{|c|c|c|c|c|c|c|}
\hline Dimension & $\begin{array}{l}\text { Operational } \\
\text { Indicator }\end{array}$ & Item & Mean & Remark & Mean & Remark \\
\hline \multirow{8}{*}{$\begin{array}{l}\text { The ecotourism } \\
\text { dimension }\end{array}$} & \multirow{8}{*}{$\begin{array}{l}\text { Low-carbon } \\
\text { tourism experience }\end{array}$} & Provide tourists with environmental education about low-carbon tourism & 4.25 & & 4.00 & \multirow{3}{*}{ removed } \\
\hline & & Ensure tourists can understand the spirit of low-carbon tourism & 4.08 & & 3.92 & \\
\hline & & Design travel itineraries for tourists to experience low-carbon tourism features & 4.33 & & 4.00 & \\
\hline & & Low-carbon ecotourism experiences (time) as a proportion of an entire trip & 3.67 & removed & 3.83 & removed \\
\hline & & $\begin{array}{c}\text { Tourists' satisfaction with travel itineraries that reflect the low-carbon } \\
\text { tourism experience }\end{array}$ & 3.75 & removed & 3.58 & removed \\
\hline & & $\begin{array}{c}\text { Whether travel itineraries enable tourists to experience the importance of } \\
\text { environmental sustainability }\end{array}$ & 4.25 & & 3.92 & \multirow[t]{3}{*}{ removed } \\
\hline & & Whether travel itineraries represent ecological features and the value of local nature & 4.33 & & 4.25 & \\
\hline & & Design special activities for tourism experiences & 3.92 & removed & 4.42 & \\
\hline
\end{tabular}

Table 7. Indicators of the social collaboration dimension.

\begin{tabular}{|c|c|c|c|c|c|c|}
\hline Dimension & $\begin{array}{c}\text { Operational } \\
\text { Indicator }\end{array}$ & Item & Mean & Remark & Mean & Remark \\
\hline $\begin{array}{l}\text { The social } \\
\text { collaboration } \\
\text { dimension }\end{array}$ & $\begin{array}{l}\text { Community } \\
\text { development }\end{array}$ & $\begin{array}{c}\text { Collaboration with local industries regarding low-carbon issues } \\
\text { Community development associations' participation in resolving low-carbon issues } \\
\text { Engage in collaboration that exerts positive economic impacts related to low-carbon issues } \\
\text { Exert and extend community industries and development }\end{array}$ & $\begin{array}{l}4.08 \\
3.92 \\
4.08 \\
4.08\end{array}$ & removed & $\begin{array}{l}3.58 \\
3.75 \\
3.67 \\
3.67\end{array}$ & $\begin{array}{l}\text { removed } \\
\text { removed } \\
\text { removed } \\
\text { removed }\end{array}$ \\
\hline
\end{tabular}




\subsection{Case Checklists}

The Case Checklist refers to the application of the indicators obtained from the local region for checking.

\subsubsection{Pushin Ranch Checklist}

Table 8 shows the checklist of Pushin Ranch.

\subsubsection{Lishan Farm Checklist}

Table 9 shows the checklist of Lishan Farm.

\subsection{Results}

1. The $t$ values were all within the confidence intervals, no significant differences existed between the means of the paired samples. Among the indicators of the organizational management and operation dimensions of facility regulations, the following two indicators were not considered features of Taiwan: "Use nontoxic agricultural products certified by the government as much as possible" and "Provide showers instead of bathtubs". Furthermore, the following two indicators were not features of China: "Avoid introducing too many artificial recreational facilities" and "Increase the ratio of food waste recycled." Both in Taiwan and China, "Landscape design should be integrated into the local natural environment" exhibited the highest score;

2. Regarding "Control over the total carrying capacity," all the related indicators were included in Taiwan, whereas one related indicator was not included in China, namely the "Control the tourism carrying capacity." Both in Taiwan and China, the greatest importance was attached to the indicator of "Flexible control over the carrying capacity according to environmental conditions"; Regarding "Stress on environmental education," all the related indicators were included in Taiwan, whereas two related indicators were not included in China, namely "Provide appropriate amounts of toiletries and reduce waste" and "Provide low-carbon environmental lectures." "Provide appropriate amounts of toiletries and reduce waste" exhibited the highest score in Taiwan, whereas "Advise customers not to change bed sheets and towels every day" and "Provide information about saving water and energy to customers" had the highest scores in China;

3. Regarding "Low-carbon tourism experience," three related indicators were not included in Taiwan: "Design special activities for tourism experiences," "The proportion of low-carbon ecotourism experience (time) of an entire trip," and "Tourists' satisfaction with travel itineraries that reflect the low-carbon tourism experience"; whereas four related indicators were not included in China: "Tourists can understand the spirit of low-carbon tourism," "Whether travel itineraries enable tourists to experience the importance of environmental sustainability," "The proportion of low-carbon ecotourism experience (time) of an entire trip," and "Tourists' satisfaction with travel itineraries that reflect the low-carbon tourism experience." In Taiwan, the indicators of "Design travel itineraries for tourists to experience low-carbon tourism features" and "The travel itinerary can represent ecological features and the value of local nature" had the highest scores. Furthermore, greater importance was attached to "Design special activities for tourism experiences" in China;

4. In terms of "Community development," only one indicator was not included in Taiwan: "Community development associations' participation in resolving low-carbon issues;" specifically, three related indicators were included in Taiwan and no related indicators were included in China. Overall, a total of 36 indicators were included in Taiwan, whereas 29 were included in China;

5. The Pushin Ranch checklist Table 8 presents the results of the examination with the 36 indicators in Taiwan. They indicate that the case complied with 17 of the target indicators. The Lishan Farm checklist Table 9 presents the results of the examination with the 29 indicators in China. They indicated that the case complied with 13 of the target indicators. 
Table 8. Checklist: the low-carbon indicators of the leisure industry with Pushin Ranch as the example.

\begin{tabular}{|c|c|c|c|c|}
\hline Dimension & Operational Indicator & Item & Test & Remark \\
\hline \multirow{22}{*}{$\begin{array}{l}\text { The organizational } \\
\text { management and } \\
\text { operation dimension }\end{array}$} & Facility regulations & Landscape design should be integrated into the local natural environment & & \\
\hline & REDUCE & Perform construction using eco-engineering as much as possible & $\sqrt{ }$ & Design is according to government regulations \\
\hline & REUSE & Ensure proper disposal of waste (insuring or outsourcing) & $\sqrt{ }$ & Outsourced to qualified agencies \\
\hline & RECYCLE & Thoroughly collect and classify garbage & $\sqrt{ }$ & according to government regulations \\
\hline & & Use local plants & & $80 \%$ of the plants used are local \\
\hline & & Purchase seasonal yields and reduce expenses on low-temperature preservation & & \\
\hline & & Use natural ventilation and reduce the energy consumption of air conditioning & & \\
\hline & & $\begin{array}{c}\text { Preserve the original landscape as much as possible and avoid constructing too many } \\
\text { basic facilities }\end{array}$ & & \\
\hline & & Implement proper logistic management and reduce the scrap rate & & \\
\hline & & Adequately use local energy and resources (solar, wind and water energy) & & \\
\hline & & Recreational facilities' design and construction should comply with safety criteria & $\sqrt{ }$ & $\begin{array}{l}\text { Design is according to government regulations } \\
\text { and safety concerns }\end{array}$ \\
\hline & & Avoid introducing too many artificial recreational facilities & $\sqrt{ }$ & Mainly ranch prairie and trees \\
\hline & & Use local materials to integrate recreational facilities into nature & & \\
\hline & & Purchase eco-labeled products & $\sqrt{ }$ & Government regulations are obeyed \\
\hline & & $\begin{array}{l}\text { Use energy-saving electronic appliances } \\
\text { Increase the ratio of food waste recycled }\end{array}$ & $\sqrt{ }$ & Power-saving lighting facilities are used \\
\hline & & The provision of accommodation and food involves ecological concepts & $\sqrt{ }$ & Recycled tableware is used \\
\hline & & Use dual-flush and low-flow toilets & $\sqrt{ }$ & Dual-flush toilets are used \\
\hline & & $\begin{array}{l}\text { The management of accommodation and food involves ecological concepts } \\
\text { Transform existing facilities and avoid redevelopment as much as possible }\end{array}$ & $\sqrt{ }$ & Yields of the season are used in the food \\
\hline & $\begin{array}{l}\text { Control over the total } \\
\text { carrying capacity }\end{array}$ & Flexible control over the carrying capacity according to environmental conditions & & \\
\hline & & $\begin{array}{l}\text { Control tourism carrying capacity } \\
\text { Total carrying capacity design }\end{array}$ & & \\
\hline & $\begin{array}{l}\text { Stress on environmental } \\
\text { education }\end{array}$ & Provide appropriate amounts of toiletries and reduce waste & $\sqrt{ }$ & $\begin{array}{c}\text { Customers are advised to bring their own } \\
\text { toiletries }\end{array}$ \\
\hline & & $\begin{array}{l}\text { Advise customers not to change bed sheets and towels daily } \\
\text { Ask customers to properly separate garbage and recycle useful resources } \\
\text { Provide information on water and energy conservation to customers } \\
\text { Provide low-carbon environmental lectures }\end{array}$ & $\sqrt{ }$ & $\begin{array}{l}\text { Garbage cans are provided for separation } \\
\text { Related slogans are shown in toilets }\end{array}$ \\
\hline \multirow{5}{*}{$\begin{array}{l}\text { The ecotourism } \\
\text { dimension }\end{array}$} & & The travel itinerary can represent ecological features and the value of local nature & $\sqrt{ }$ & Plants tours are provided \\
\hline & Low-carbon tourism & Design the travel itinerary for tourists to experience low-carbon tourism features & $\sqrt{ }$ & Plants tours are provided \\
\hline & experience & $\begin{array}{c}\text { Whether the travel itinerary allows tourists to experience the importance of } \\
\text { environmental sustainability }\end{array}$ & $\sqrt{ }$ & Plants tours are provided \\
\hline & & Tourists can understand the spirit of low-carbon tourism & & \\
\hline & & Tourists receive environmental education about low-carbon tourism & & \\
\hline \multirow{3}{*}{$\begin{array}{l}\text { The social } \\
\text { collaboration } \\
\text { dimension }\end{array}$} & & Collaboration with local industries regarding low-carbon issues & & \\
\hline & Community development & Exert and extend community industries and development & & \\
\hline & & Engage in collaboration that exerts positive economic impacts related to low-carbon issues & & \\
\hline
\end{tabular}


Table 9. Checklist: the low-carbon indicators of the leisure industry with Lishan Music Farm as the example.

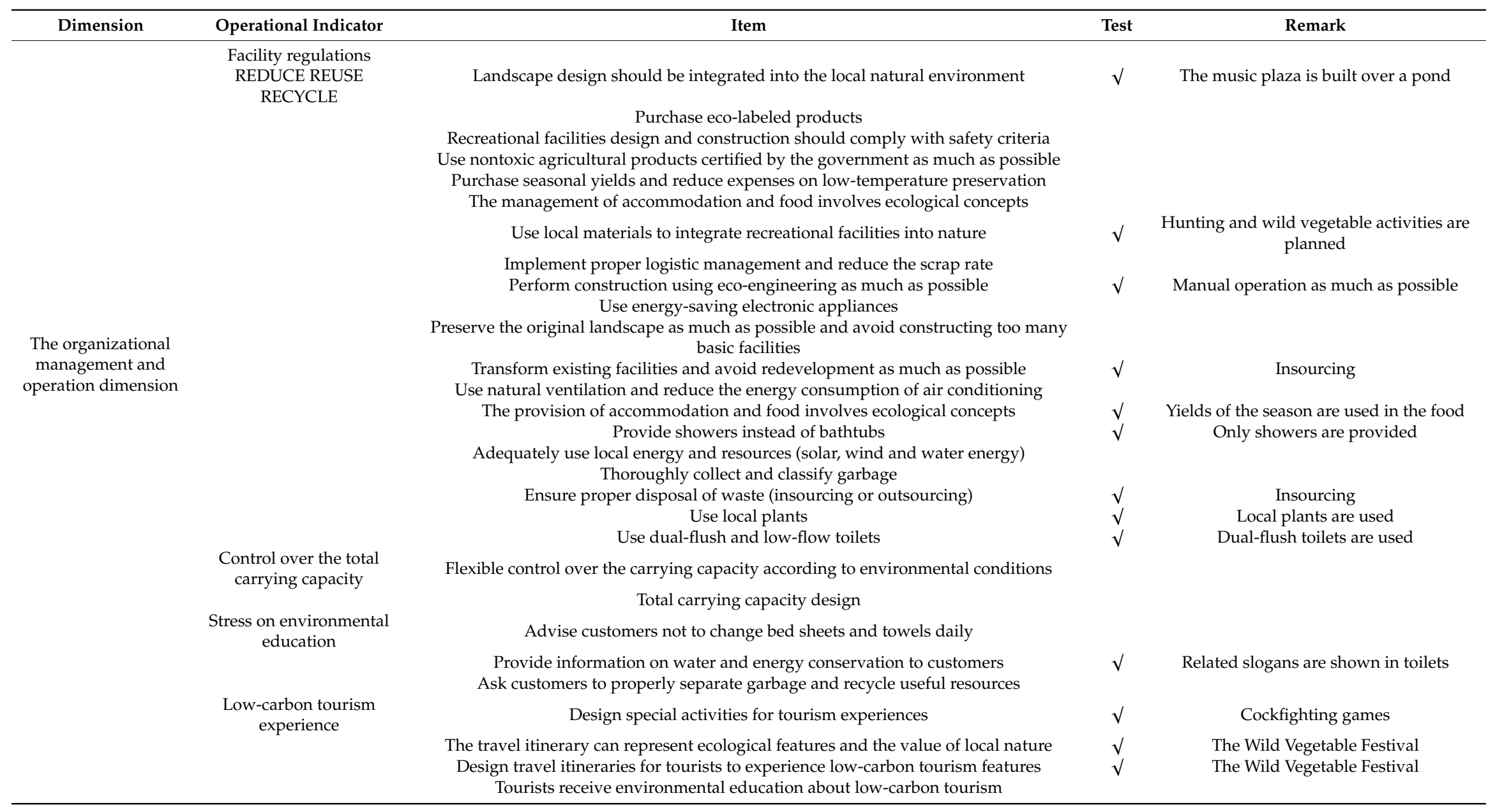




\section{Discussion}

1. Facility regulations: in both Taiwan and China, the organizational management and operation dimensions were considered the most important. In terms of "Facility regulations," "Landscape design should be integrated into the local natural environment" was the most important. Accordingly, all experts attached the greatest importance to how the leisure industry implies the low-carbon concept in landscape design while integrating it with the local natural environment. Characteristics of a natural tourism landscape include (1) naturalness and simplicity, (2) seasonality and timeliness, (3) regionality and zonality, (4) diversity and integrity and (5) sustainability and non-renewability. We must complete these goals. This result corresponds with $\mathrm{Lu}$ [11] and the indicators and criteria for evaluating the development potential of low-carbon tourism in Taiwan's scenic areas. Regarding the Taiwanese leisure industry, an unexpected research result observed in this study was that "Use nontoxic agricultural products certified by the government as much as possible" was not included as an indicator. Furthermore, "Purchase eco-labeled products" was listed as the most important indicator in China, whereas the Taiwanese industry only considered it the 11th most important indicator. This implies how, for example, the series of food safety scandals in Taiwan from 2013 to 2014 have caused consumers to show a long lasting concern about the food certification system therein (Foodnext [24], 2019). According to our survey data, lower scores were mainly given by experts from the industrial sector. Consequently, the governments' active effort is required along with assistance provided by academia to re-establish the public's confidence in the food certification system. This corresponds to the argument of Kuo [25] who stated that, subject to the trend of globalization, particular attention should be paid to food safety in Taiwan. For example, the incident of plasticizer-contaminated food should raise significant concerns. In addition, "Provide showers instead of bathtubs" was not listed as an indicator. This result might be influenced by the Japanese bathing culture introduced to Taiwan during Japan's rule, in addition to the seemingly enduring habit of using bathtubs in Taiwan. Younger people in Taiwan tend to take showers instead of using bathtubs [26]. Thus, enhanced results could be achieved through greater governmental efforts in promoting the use of showers instead of bathtubs. Given China's economic development, experts from the industrial, governmental and academic sectors did not give high scores to "Avoid introducing too many artificial recreational facilities" and "Increase the ratio of food waste recycled." Consequently, the Chinese government is advised to take the initiative in improving these aspects. In Taiwan, achievements in garbage classification and resource recycling owe much to the government's initial direction, as well as the public's positive response, which can serve as a reference for China;

2. Control over the total carrying capacity: in terms of "Control over the total carrying capacity," the greatest importance was attached to the indicator of "Flexible control over the carrying capacity according to environmental conditions" in both Taiwan and China. In China, "Control tourism carrying capacity" was not included as an indicator mainly because of the low scores given by the industrial sector. As for Taiwan, a general consensus existed regarding tourism and service quality. Thus, the Chinese government and academia are advised to promote the demand for tourism quality and establish strict regulations. Similarly, low scores by the industrial sector in China led to the exclusion of two indicators: "Provide appropriate amounts of toiletries and reduce waste" and "Provide low-carbon environmental lectures." Regarding personal cleaning products, demand exists from consumers in China, whereas the demand for low-carbon lectures is lower. Therefore, the Chinese governmental, academic and industrial sectors must jointly promote low-carbon education to educate consumers and change their behaviors. Total control is necessary for sustainable development. In environmental management, a management plan must precede the total carrying capacity. Different management plans and risk acceptance have different amounts of carrying capacity;

3. Low-carbon tourism experience: as for "Low-carbon tourism experience," the indicator of "The travel itinerary can represent ecological features and the value of local nature" was agreed 
on in both Taiwan and China; "The proportion of low-carbon ecotourism experience (time) of an entire trip," "Tourists' satisfaction with travel itineraries that reflect the low-carbon tourism experience, and "Design special activities for tourism experiences" were not included as indicators. According to the survey data, the reason for this might be the low scores given by the industrial sector; therefore, technology products can be used to facilitate innovative ecotourism experiences. In China, the indicators of "Tourists can understand the spirit of low-carbon tourism," "Whether travel itineraries enable tourists to experience the importance of environmental sustainability," "The proportion of low-carbon ecotourism experience (time) of the entire trip," and "Tourists' satisfaction with travel itineraries that reflect the low-carbon tourism experience" were not included; this is mainly because of the low scores given by the industrial sector. Therefore, the government and academia are advised to promote related ideas, help the industrial sector solve problems, as well as provide incentives to increase industry awareness. Low-carbon tourism is an emerging strategy currently promoted in Taiwan. It refers to tourism that considers the reduction of carbon emissions. The combination of mass rapid transportation, passenger transport, and bicycle tourism can minimize carbon dioxide emissions. Joint efforts are required to reduce carbon emissions;

4. Community development: regarding "Community development," the indicator of "Community development associations' participation in resolving low-carbon issues" was not included in Taiwan, but the score was only 0.08 less than the threshold score. Thus, community development associations in Taiwan are advised to work more on low-carbon issues, increasing the concern and participation of the industrial, governmental and academic sectors. By contrast, no related indicators were included in China; the reason might be its different political system and insufficient urban infrastructure causing lower low-carbon awareness among its citizens [27], whereas in Taiwan, under its democratic system, people have a higher awareness. In Taiwan, greater efforts are invested into community promotion; "Collaboration with local industries regarding low-carbon issues," "Engage in collaboration that exerts positive economic impacts related to low-carbon issues," and "Exert and extend community industries and development" were all included as important indicators. The results correspond with Luo's study [28] "Planning for the Low Carbon Community Development Strategy-A Case study on Linbei Village, Linnei Township, Yunlin County.";

5. Case studies: in the case studies, Pushin Ranch complied with $47 \%$ of the indicators in Taiwan, and Lishan Music Farm complied with $45 \%$ of the indicators in China. As for the organizational management and operation dimension, both Pushin Ranch and Lishan Music Farm were aware of carbon reduction, but the facilities in both places remained inadequate because of investment considerations; the pressure of operation similarly led to less attention toward carrying capacity management. Pushin Ranch performed more effective garbage classification and collection as well as waste management while attaching more importance to environmental education, which involves the common awareness of the government and the public. Regarding the ecotourism dimension, both cases actively promoted low-carbon ecotourism; Pushin Ranch attached more importance to education and promotion, whereas Lishan Music Farm stressed holding special activities instead. As for the social collaboration dimension, it was included as an indicator in Taiwan, but community activities were rare around Pushin Ranch because of its location adjacent to an industrial district. Therefore, this study recommends that Pushin Ranch co-organizes activities with the government, the industry and academia in the future;

6. Future research recommendations: the leisure industry covers a rather broad range of activities. This study targeted Pushin Ranch in Taoyuan, Taiwan and Lishan Music Farm in Nanjing, China as examples to perform preliminary research on conceptual indicators, attempting to establish a set of low-carbon indicators for similar attractions in the leisure industry. However, because of the different political systems adopted by the two countries, although both countries agree on certain items, it is Taiwan that attaches greater importance to community management and 
promotion. Therefore, future research should further classify different business activities in the leisure industry and establish their own indicators. In this study, the indicator selection method stressed the levels of importance and stability. The adequacy of an indicator was affected by the diversity in the experts' specialties. However, determining the importance or stability of an indicator by using numbers solely may cause some crucial indicators to be removed while overlooking the importance of careful communication among the experts. Future researchers may consider contexts, societies, technologies, cultures and economic growth to supplement industrial, governmental, and academic experts' opinions. This enables extending the meaning and value of the indicators in addition to solely using numbers to indicate the similarities and differences of these indicators in distinct contexts;

7. Carbon-emission: the UN has started to discuss carbon-emission trading systems. Future research can include indicators about $\mathrm{CO}_{2}$ emissions to establish implementation criteria regarding energy-saving and carbon-emission reduction.

\section{Conclusions}

1. The results of this study are presented in three dimensions. (1) Organizational management and operation: the integration of landscape design and local natural environments is a focal indicator for Taiwan and China. This indicator exhibited the best performance in both cases. This result is consistent with the 2030 sustainable development goal for addressing climate change. Taiwanese indicators did not include "Use nontoxic agricultural products certified by the government as much as possible." Compared with indicators in China that ranked "Purchase eco-label products" as the top priority, Taiwan must promote relevant measures to restore consumer confidence. For the indicator "Provide showers instead of bathtubs," China outperformed Taiwan. Promotion in Taiwan resulted in improvements. Although "Control the total carrying capacity" was listed as an indicator, the case examination results were unsatisfactory, and further collaborative efforts are required from the industry, the government and academia. Both Taiwan and China listed "Ask customers to properly separate garbage and recycle useful resources" as an indicator and implemented practical measures. (2) Ecotourism: both Taiwan and China hosted guided tours and activities. In particular, China was more dedicated to hosting special activities, which can include low-carbon tourism experiences. (3) Social collaboration: none of the indicators in this dimension applied for the case in China. We recommend increased industry-government-academia collaboration, low-carbon education promotion through community collaboration and more frequent activity sessions to increase people's opportunities to participate in these activities. Although Taiwan included these indicators, practical implementation should be improved for this case. A total of 36 indicators were retained for Taiwan (Pushin Ranch met 17) and 29 were retained for China (Lishan Farm met 13). This allows industrial, governmental and academic units to establish management models and assessment indicators for the leisure industry to meet the demands of energy conservation and carbon reduction;

2. As of 2020, the COVID-19 epidemic is spreading globally. Governments of various countries are actively searching for successful epidemic-prevention targets; the CNN(Cable News Network) of the United States consolidated the anti-epidemic measures of Taiwan, Iceland, Germany and South Korea and ranked Taiwan's experience in first place. In these countries, carrying capacity control is a crucial measure. Night markets, markets, commercial districts, department stores, playgrounds, scenic areas, national parks and religious centers are all subject to safety restrictions to prevent cluster infections. Therefore, this experience should be used in the management of the leisure industry to provide high-quality services, save energy and reduce emissions.

3. In Taiwan, greater importance is attached to the indicator of "The travel itinerary can represent ecological features and the value of local nature." Low-carbon tours have been held in Pinglin by the New Taipei City Government, and the Tourism Bureau and the Environmental Protection Administration have promoted low-carbon and sustainable tourism projects. In 2019, the annual 
tourism theme of Taiwan was "Small Town Ramble," whereas in 2020 it is the "Year of Mountain Tourism." The government continues to promote the brand image of Taiwan tourism, which integrates eco-awareness and community-building concepts in relation to energy saving and carbon emission reduction, encouraging the public to participate more in local activities. In October 2019, the accommodation booking website Booking.com announced that, compared with the general behavior of tourists worldwide, Taiwanese tourists have greater environmental awareness and depend more on technology; furthermore, Taiwanese tourists agree more with low-carbon tourism and community development, whereas Taiwan's industrial, governmental and academic sectors more actively use technology to promote paperless operations. Moreover, almost two thirds $(66 \%)$ of Taiwanese tourists wish to contribute to alleviating the problems concerning over-tourism, whereas $53 \%$, acknowledging the burden of over-tourism on the environment, are willing to choose similar destinations as a substitute for more popular or crowded tourist attractions. Compared with the mean scores worldwide (54\% and 51\%), Taiwanese people have greater tourism awareness on contributing to environmental conservation (Taipei City, 2019); Therefore, related promotions and development in Taiwan can serve as references for China

4. The United Nations Environment Program published the Emissions GAP Report 2019, which revealed that the world is projected to fail to limit warming to within $1.5^{\circ} \mathrm{C}$ by 2030 . Therefore, carbon reduction needs urgent solutions. So far, the global average temperature has risen by $1.1^{\circ} \mathrm{C}$, and this will displace numerous households and communities. Between 2020 and 2030, more active carbon reduction initiatives are necessary to reduce carbon emissions by $7.6 \%$ per year and limit the global temperature rise to within $1.5^{\circ} \mathrm{C}$. Failure to act immediately will render this goal unattainable. With the rapid growth of the tourism market, carbon management indicators for the leisure industry, involving mutual support among the academia, industry and government to meet the requirements, can contribute to achieving the designated carbon reduction goal by 2030; Scott et al., [29] (2019) argue that climate change will pose an increasing barrier to tourism's contributions to the UNSDGs. Seventy-one countries and 11 regions worldwide have resolved to achieve the long-term goal of zero carbon emissions. However, these countries and regions account for only $15 \%$ of global warming gas emissions. No commitments to improvement have been made by $85 \%$ of countries and regions. In G20 countries, only the United Kingdom and France have legislated to achieve the long-term goal of zero carbon emissions, although countries in the European Union (i.e., Germany and Italy) are in the process of establishing relevant legislation. However, the remaining $15 \mathrm{G} 20$ countries have shown no sign of establishing laws to achieve zero carbon emissions. Therefore, achieving the goal by 2030 is challenging. World leaders have advocated to initiate movements, realize sustainable development goals and provide well thought out solutions at the sustainable development committee in September 2019. Scott et al. [4] (2008) recommended the following measures: setting targets for energy conservation and efficiency; applying benchmarking certifications; and integrating sustainability and customer comfort. This study focused on the establishment of low-carbon indicators for the leisure industry in Taiwan and China. It is also the goal this study hopes to achieve. The difference between leisure industries in democratic and socialist regimes provided information regarding indicators and priority orders in different environments. Case examinations revealed that further improvement is required to achieve the indicator goals. This pilot study tested ideas for the investigation of indicators for leisure industries in different regimes. We hope for the results to attract due attention from relevant industries, governments and academics worldwide and to provide a reference for low-carbon management in the global leisure industry. Modification may be required to achieve carbon reduction requirements according to real contexts to address the challenges of climate change and crisis by 2030 and achieve the goal of sustainable development. This study contribute to consideration of climate change should be strengthened in tourism development plans [29]. 
5. The literature review indicated the absence of comparative studies on low-carbon management indicators for the leisure industry in Taiwan and China. The researchers hope that future studies will continue to supplement this study to contribute to the Earth through saving energy and reducing carbon emissions.

Author Contributions: Conceptualization, H.-Y.S. and Y.-S.Y.; methodology, H.-Y.S. and Y.-S.Y.; validation, H.-Y.S. and Y.-S.Y.; curation, H.-Y.S. and Y.-S.Y.; supervision, H.-Y.S.; software, Y.-S.Y.; formal analysis, Y.-S.Y.; investigation, Y.-S.Y.; data, Y.-S.Y.; writing—original draft preparation, Y.-S.Y.; writing—review and editing, Y.-S.Y. All authors have read and agreed to the published version of the manuscript.

Funding: This research received no external funding.

Conflicts of Interest: The authors declare no conflict of interest.

\section{References}

1. Climate Change, Global Warming and UN's Mission. Available online: https://www.bbc.com/zhongwen/ trad/chinese-news-46450010 (accessed on 5 January 2020).

2. $8 \%$ of the Global Carbon Emission Derives from Tourism. Experts Suggest to Charge for Carbon Footprint. Available online: Technews.tw/2018/05/09/tourism-add-carbon-emission-worse (accessed on 28 November 2019).

3. Greenpeace: China's Carbon Emission Acceleration in 2018 Was the Fastest in the Last 6 Years. Available online: Cha.com.tw/news/lan/201805300286.aspx (accessed on 3 June 2019).

4. Scott, D.; Amelung, B.; Ceron, J.; Dubois, G.; Gossling, S.; Peeters, P.; Simpson, M.C. Climate Change and Tourism: Responding to Global Challenges; World Tourism Organization: Madrid, Spain, 2008.

5. Low-Carbon Tourism. Available online: http://www.lowcarbonmne.me/en/about-us/low-carbon-tourism (accessed on 20 May 2020).

6. Simpson, M.C.; Gossling, S.; Scott, D.; Hall, C.M.; Gladin, E. Climate Change Adaptation and Mitigation in the Tourism Sector: Frameworks, Tools and Practices; UNWTO: Madrid, Spain, 2008.

7. Tang, Z.; Shi, C.; Liu, Z. Sustainable development of tourism industry in China under the low-carbon economy. Energy Procedia 2011, 5, 1303-1307. [CrossRef]

8. Lee, T.W. Cognition, Attitudes, Subjective Norms, and Behavioral Intentions of Tourists on the Low-Carbon Tourism-The Study of Tsengwen Reservoir. Master's Thesis, Department of Toursim Management, Nanhua University, Chiayi, Taiwan, 2012.

9. Tsai, M.H. Studying Low-Carbon Tours' Certified Standard for Travel Agencies in Taiwan. Master's Thesis, Graduate Institute of Hospitality, National Kaohsiung University of Hospitality and Tourism, Kaohsiung, Taiwan, 2012.

10. Chen, C.H. Study on Establishing an Indicator System for Developing Low-Carbon Travel in Taiwan. Master's Thesis, Graduate Institute of Hospitality, National Kaohsiung University of Hospitality and Tourism, Kaohsiung, Taiwan, 2011.

11. Lin, C.K.; Wang, C.C.; Pan, M.S.; Chiang, C.Y.; Lin, H.L.; Shih, C.H. Construction of evaluation indicators on the green hotel. J. Leis. Recreat. Manag. 2015, 2, 57-83.

12. Lu, C.H. Comparative Study on the Development Potential of Low-Carbon Tours to Scenic Areas in Taiwan. Master's Thesis, Environmental Engineering Department, Da-Yeh University, Changhua, Taiwan, 2010.

13. Tsao, T. Establishing the Indicators of Low-Carbon Community Tourism. Master's Thesis, Department of Toursim, Providence University, Taichung, Taiwan, 2013.

14. Wang, Y. A Study of Taiwan's Low-Carbon Tourism Development Suitability Evaluation Model. Ph.D. Thesis, Chung Hua University Ph. D. Program of Technology Management, Hsinchu, Taiwan, 2015.

15. Lin, Y.C. The Development for Sustainable Tourism Indicators: From Perception Perspective. Master's Thesis, Tourism Management Department, Chinese Culture University, Taipei, Taiwan, 2002.

16. Zo, S.N. Study on Planning for Sustainable Tourism Development: A Case Study on the Northeast Coast National Scenic Area. Ph.D. Thesis, Department of Geology, National Taiwan University, Taipei, Taiwan, 2002.

17. The Delphi Method. Available online: https://www.investopedia.com/terms/d/delphi-method.asp (accessed on 20 May 2020). 
18. Doke, E.R.; Swanson, N.E. Decision variables for selecting prototyping in information systems development: A Delphi study of MIS managers. Inf. Manag. 1995, 29, 173-182. [CrossRef]

19. Murry, J.W.; Hammons, J.O. Delphi: A versatile methodology for conducting qualitative research. Rev. High. Educ. 1995, 18, 423-436. [CrossRef]

20. Delp, P.; Thesen, A.; Motiwalla, J.; Seshadri, N. Delphi: System Tools for Project Planning, Columbus, National Center for Research in Vocation Education; The Ohio State University: Columbus, OH, USA, 1977.

21. Cheng, W.Y. Development Right Transferred into Local Socio-Economic Environment Influencing the Construction of Estimation Indicators: With Old City Streets Preservation as Example. Master's Thesis, Feng Chia University Department of Land Management, Taichung, Taiwan, 1997.

22. Linstone, H.A.; Turoff, M. The Delphi Method: Techniques and Applications; Addison-Wesley: Reading, MA, USA, 1975.

23. Hsieh, C.H. The Evaluation of Applicability to Urban Sustainable Indicators: A Case Study of Kaohsiung. Master's Thesis, Institute of Public Affairs Management, National Sun Yat-sen University, Kaohsiung, Taiwan, 2002.

24. Recurrent Food Safety Incidents! Only CAS Best Stands the Test. Available online: Foodnext.net/news/ newssafe/paper/559326877/ (accessed on 28 November 2019).

25. Kuo, N.W. Local Production for Local Consumption: The Mainstreaming of Green Diets; Economic Daily News, A12 Leisure Agriculture Column: Taipei, Taiwan, 2011.

26. Chen, J.Z. Environmental Improvement and Popularize Plan of Water Conservation; Water Resources Agency, Ministry of Economic Affairs: Taipei, Taiwan, 2006.

27. Current Low-Carbon Development in Cities in China. Available online: Tesd.org.tw/enp/topic_reports.php? ec $=8 \&$ iid $=24$ (accessed on 19 November 2019).

28. Luo, Y.W. Planning for Low Carbon Community Development Strategy-A Case Study on Linbei Village, Linnei Township, Yunlin County. Master's Thesis, Transworld University, Yunlin, Taiwan, 2013.

29. Scott, D.; Gossling, S.; Hall, C.M.; Hall, C.M. Global Tourism Vulnerability to Climate Change Annals of Tourism Research; ELSEVIER: Amsterdam, The Netherlands, 2019; Volume 77, pp. 49-61.

(C) 2020 by the authors. Licensee MDPI, Basel, Switzerland. This article is an open access article distributed under the terms and conditions of the Creative Commons Attribution (CC BY) license (http://creativecommons.org/licenses/by/4.0/). 